\title{
THE MANAGEMENT MODEL OF MASCETI PURA TEMPLE AREA IN BALI AS A SPIRITUAL TOURISM DESTINATION BASED ON LOCAL WISDOM
}

\author{
I Gede Wirabuana Putra 1, Wayan Maba 1, I Ketut Widnyana $₫$ iD *1, Anak Agung \\ Ketut Sudiana ${ }^{1}$
}

${ }^{* 1}$ Masters in Regional Planning and Environmental Management, Postgraduate Program at Mahasaraswati Denpasar University, Indonesia

DOI: https://doi.org/10.29121/granthaalayah.v9.i2.2021.3653

Article Type: Research Article

Article Citation: I Gede Wirabuana Putra, Wayan Maba, I Ketut Widnyana, and Anak Agung Ketut Sudiana. (2021). THE MANAGEMENT MODEL OF MASCETI PURA TEMPLE AREA IN BALI AS A SPIRITUAL TOURISM DESTINATION BASED ON LOCAL WISDOM. International Journal of Research -GRANTHAALAYAH, 9(2), 291-298.

https://doi.org/10.29121/granthaa layah.v9.i2.2021.3653

Received Date: 26 January 2021

Accepted Date: 28 February 2021

Keywords:

Spiritual Tourism

Masceti Temple Sacred Area Local Wisdom

\begin{abstract}
Research on the management model of the sacred area of the Masceti temple as a spiritual tourism destination aims to identify the potential for tourism in the sacred area of the Masceti temple to be developed into a spiritual tourism destination based on local wisdom, explore and study community attitudes, and formulate strategies for developing the sacred area of the Masceti temple as a spiritual tourism destination. This research is a qualitative descriptive study with data collection methods through observation, interviews, questionnaires and documentation. The results showed that the sacred area of Masceti temple has the potential for spiritual, cultural and natural tourism. Supporting facilities such as road access and additional services available in the area are included in the good category. The community's perceptions and attitudes agree with the development of the management of the sacred area of the Masceti temple as a spiritual tourism destination based on local wisdom. Based on the I-E matrix, it is shown that the sacred area of the Masceti temple has strong internal and external conditions. The strategy in accordance with these conditions is a growth strategy. The SWOT analysis resulted in the following alternatives a) finalizing the planning of the arrangement of the Masceti temple sacred area and implementing sustainable arrangement, b) arranging the place for selling souvenirs, culinary delights and arranging the parking area, c) improving supporting facilities and infrastructure such as toilets, landfills, yoga places, meditation, holy bathing and construction of Hindu dormitories.
\end{abstract}

\section{INTRODUCTION}

The tourism sector is one of the leading sectors which contributed 5.25\% to Indonesia's Gross Domestic Product (Ministry of Tourism, 2018). The development of Indonesia's tourism sector is supported by the Government Regulation Number 50 of 2011 concerning the National Tourism Development Master Plan (RIPPARNAS) 20102025. In addition, it is supported by the target of visiting 20 million foreign tourists by 2019 (Kompas, 2014). Arrival of a tourist will require temporary shelter, food and transportation. The needs of these tourists can be met by other sectors around tourist destinations, so that tourism is said to be able to encourage other sectors (Irma et al. 2015). However, apart from its positive impacts, tourism activities can have a negative impact on environmental, socio-

(C) 2021 The Author(s). This is an open access article distributed under the terms of the Creative Commons Attribution License, which permits unrestricted use, distribution, and reproduction in any medium, provided the original author and source are credited. 
cultural and economic aspects. Bali is one of the provinces in Indonesia which has tourist attractions that motivate tourists to come to visit, such as natural beauty, culture, crafts, culinary, and recreation. As a tourist destination, the tourism potential on the island of Bali causes a strong attraction for tourism visits, both local and foreign tourists. Recently in Bali, the development of spiritual tourism has started to be discussed a lot, some even predict that spiritual tourism will soon be 'booming' in the next few years. Spiritual tourism is an alternative tourism which is being promoted by the government. World Travel and Tourism Review stated that alternative tourism is an effort to move away from a mass tourism approach to one in which a more specialized tourism experience is offered in a more personal and culturally sensitive way (Naisbitt in kusuma et al. 2016) In addition to experiencing negative impacts on the environment, also to socio-culture based on local wisdom as a distinctive identity of Balinese tourism. Considering that the greatest potential of Indonesian tourism, especially Bali, is nature and culture related to spirituality, to maintain the sustainability of the existence of the two tourism potentials, especially spiritual cultural tourism, innovation can be carried out as an alternative effort to develop unique, new and interesting tourism destinations.

The implementation of development in the tourism sector is carried out by upholding religious norms and cultural values as the embodiment of the concept of life in a balanced relationship between humans and God Almighty, the relationship between humans and fellow humans, and the relationship between humans and the environment; uphold human rights, religious culture, and local wisdom. Tourism should provide benefits for the welfare of the people, justice, equality, preserving nature and the environment; , empowering local communities, ensuring integration between sectors, between regions, between the center and regions which constitute one systematic unit within the framework of regional autonomy, and strengthening the integrity of the Unitary State of the Republic of Indonesia (Kemenbudpar, 2009).

The purpose of this research is to identify the tourism potential of the Masceti temple sacred area to be developed into a spiritual tourism destination based on local wisdom, to explore and study people's attitudes towards developing the management of the sacred area of the Masceti temple as a tourist destination, and formulate a strategy for developing the sacred area of the Masceti temple as a spiritual tourism destination based on local wisdom. The problems that exist in the sacred area of Pura Masceti are the unfulfilled needs of visitors, the existence of inadequate facilities and infrastructure, and the lack of order in the management system of tourist destinations. In addition, the role of stakeholders to participate in promoting these destinations is basically still low. The arrangement of the sacred area of the Masceti temple is expected to be an alternative to the development of environmentally friendly spiritual tourism by preserving existing local wisdom so that it can be a different attraction from other tourist objects.

\section{MATERIALS AND METHODS}

This research is a qualitative descriptive study. The research location is the sacred area of the Masceti temple, Medahan Village, Blahbatuh District, Gianyar Regency, Bali - Indonesia Province. This research was conducted to identify the potential for tourism in the sacred area of the Masceti temple to be developed into a spiritual tourism destination based on local wisdom, to explore and study people's attitudes towards developing the management of the sacred area of the Masceti temple as a wisdom-based spiritual tourism destination and to formulate a strategy for developing the sacred area of the Masceti temple as a destination. spiritual tourism based on local wisdom, the condition of reality in the observed research location in accordance with existing phenomena and is prepared based on scientific studies, and finally formulating alternative strategies. SWOT analysis is a systematic identification of various factors to formulate a strategy. Strategies based on logic that can maximize strength (strength) and opportunities (opportunity) but simultaneously can minimize weakness (weakness) and threats (threat) (Rangkuti, 2000). The data used are secondary data and primary data. Secondary data were obtained through literature review and documents from related agencies. Primary data were collected through interviews and observations. Determination of sampling using purposive sampling with the assumption that the scope of research is limited to the location of the Masceti temple area. Respondents who were selected to be interviewed were people whose daily activities were directly involved in tourism activities at the research location and those who had knowledge regarding the conditions of tourism at the research location. Respondents include managers of the Masceti Beach tourist area, the Gianyar Regency Tourism Office, Blahbatuh District, Medahan Village, and visitors. 
The data collection techniques used were questionnaires, interviews, observation, literature study and documentation of stakeholders and community leaders. The analysis technique used in formulating a development strategy for the management of the sacred area of the Masceti temple as a spiritual tourism destination based on local wisdom is descriptive qualitative analysis.

\section{RESULTS AND DISCUSSION}

\subsection{THE TOURISM POTENTIAL OF THE MASCETI TEMPLE AREA}

The results showed that the potential that exists in the sacred area of Masceti temple are: spiritual tourism, cultural tourism, and nature tourism. a) potential for spiritual tourism, the sacred area of Masceti temple is known as the Sad Kayangan Temple in Bali. There is a sacred area in the form of Masceti Beach which is a place to carry out religious ceremonies for Hindus in Bali. The existence of the Masceti temple on the north side of the beach makes the Masceti temple have a sacred fibration / aura, so that many tourists who visit pray, take holy baths, yoga and meditation. b) the potential for cultural tourism, the sacred area of Masceti temple is also used as a place to carry out religious rituals such as the Siwaratri holiday, the implementation of the Hindu dormitories and cultural arts activities by schools and the community in Medahan Village. The sacred area of the Masceti temple is divided into 3 zones based on the Tri Mandala, the Utama Mandala zone is the Masceti temple area which is used for religious activities as a place of worship, the Madya Mandala zone is the west coast area which is a place for parking and merchant areas, while the east is used as a place to do yoga. meditation, a place to enjoy the sunrise, the Nista Mandala zone is the southern area of Masceti beach such as for melasti activities and holy bathing. c) potential for natural tourism, such as enjoying the sunrise, tourist destinations, vast expanses of rice fields, unspoiled environmental conditions.

Seeing from the potential of the Masceti temple area, the attributes as a tourist destination can be fulfilled, according to Yoeti's opinion (1985) there are 3 main characters of tourist objects that must be considered in efforts to develop a certain tourism object so that it attracts and is visited by many tourists, namely: a). The area must have what is called "something to see." This means that there must be tourist objects and tourist attractions that are different from what other regions have, the area must have a special and unique attraction. b). The area must have what is called "something to do". This means that apart from being able to see many places, recreational or amusement facilities must also be provided that can make tourists feel at home longer in that place. c). The area must have what is called "something to buy". This means that in that place there must be facilities for shopping, especially souvenir items and handicrafts of the community as souvenirs to take home. According to Conrady and Buck (2011), dividing the spiritual tourism category as follows: Interaction with nature \& exercise: pilgrimages, meditative hiking, meditative walking; With counselling : talk with pastoral worker; talk with shaman; talk with spiritual coach; With music: singing mantras, chanting, tones; With creativity: mediative painting, ikebana; With physical exercises: yoga, tai chi, meditative dances, circle dances, and With spiritual exercises: spiritual excercise (in silence), contemplation, meditation, trips to shamans

\subsection{SUPPORTING FACILITIES FOR TOURISM IN THE SACRED AREA OF THE MASCETI TEMPLE}

Supporting facilities in the sacred area of Masceti temple are public toilets, temporary trash cans, parking fields, food stalls and souvenir shops. However, the condition of the toilets is not well maintained, the trash cans are not well maintained, the parking lot is still lacking for development needs, the arrangement of the area needs to be improved to increase the attractiveness of the beach, improve the quality of toilets, improve the quality of trash bins, expand parking lots, arrange parking lots, and add to the food products and souvenirs being sold. Accessibility in the form of a road to the sacred area of the Masceti temple is in good condition, while additional facilities in the form of electricity, telecommunications, clean water networks, and security posts are in good condition. As for the development needs, it is necessary to improve the quality of street lighting with additions at several points near the coastal area. The existence of tourism infrastructure and facilities is very important and absolute to provide quality services to tourists visiting a tourist attraction (Habibah, 2006) 


\subsection{PERCEPTIONS AND ATTITUDES OF THE COMMUNITY}

Perceptions and attitudes of the people of Medahan Village towards the development of the management of the sacred area of the Masceti temple as a spiritual tourism destination based on local wisdom, it is found that $46 \%$ strongly agree and 54\% agree. . From these results, it is found that the community's perception is in the category of agreeing if the sacred area of the Masceti temple is developed into a spiritual destination based on local wisdom on the grounds that it can increase the economic growth of the community and encourage increased spiritual activity. This is in accordance with the opinion of Smith and Kelly, (2006) who state about spiritual tourism as follows: spiritual tourism as one that provides the visitor with activities and / or treatments aimed at developing, maintaining and improving the body, mind and spirit

Table 1: IFAS (Internal Strategic Factor Analysis Summary) Matrix

\begin{tabular}{|c|c|c|c|c|}
\hline No. & Internal Strategy Factors & $\begin{array}{c}\text { Weigh } \\
\mathrm{t}\end{array}$ & $\begin{array}{c}\text { Rattin } \\
\mathrm{g}\end{array}$ & $\begin{array}{c}\text { Scor } \\
\mathrm{e}\end{array}$ \\
\hline$(1)$ & $(2)$ & $(3)$ & $(4)$ & $(5)$ \\
\hline & STRENGTH (+) & & \\
\hline 1 & Gianyar Regency Spatial Plan & 0.067 & 3,7 & 0.25 \\
\hline 2 & History of the Masceti Temple Area & 0.068 & 3.8 & 0.26 \\
\hline 3 & The uniqueness of the Masceti Temple Area & 0.068 & 3.8 & 0.26 \\
\hline 4 & Masceti Temple Sacred Area & 0.068 & 3.8 & 0.26 \\
\hline 5 & There is already a place of Yoga, Bath sacred and Meditation & 0.065 & 3,7 & 0.24 \\
\hline 6 & Typical Culinary Sea Fish & 0.057 & 3,2 & 0.18 \\
\hline 7 & Beautiful expanse of rice fields & 0.065 & 3,6 & 0.23 \\
\hline 8 & Customs / culture & 0.069 & 3,9 & 0.26 \\
\hline 9 & The strategic location of Pura Masceti, access to the district center and easy & 0.068 & 3.8 & 0.26 \\
\hline 10 & access to arterial roads & & & \\
\hline 11 & Attitude of Society & 0.065 & 3,6 & 0.23 \\
\hline & District Government and Village Government Support & 0.068 & 3.8 & 0.26 \\
\hline 1 & WEAKNESS (-) & & \\
\hline 2 & Facilities and infrastructure Not yet well ordered & 0.031 & 1.7 & 0.05 \\
\hline 3 & Areas that are not well organized & 0.031 & 1.7 & 0.05 \\
\hline 4 & Environmental Cleanliness is Still Lacking & 0.031 & 1.7 & 0.05 \\
\hline 5 & Funding or budget is still lacking & 0.027 & 1.5 & 0.04 \\
\hline 6 & Human Resources Are Still Low & 0.033 & 1.9 & 0.06 \\
\hline 7 & Management management system does not yet exist & 0.026 & 1.5 & 0.04 \\
\hline 8 & Total (S + W) & 0.034 & 1.9 & 0.06 \\
\hline 9 & Institutional Governance & 0.029 & 1.6 & 0.05 \\
\hline & Pre no supporting facilities such as Hindu dormitories & 1,000 & & 3.17 \\
\hline
\end{tabular}

Source: Primary Data Analysis Results, 2020

The results of the IFE (Internal Factors Evaluation) calculation show that the main strength factor is the support of the Gianyar Regency Government and the Village Government with a score of 0.26 , the strategic location of the temple with a score of 0.26 , access to temples is easy and customs shown with a score of 0.26 , while the weaknesses such as institutional governance with a score of 0.06 . based on the internal environmental analysis above, the position of the internal environment in the development of the management of the sacred area of the Masceti temple as a spiritual tourism destination based on local wisdom is in the "strong" category with a combined score of strength and weakness is 3.17 (in the range of values 3.00 - 4.00) 
I Gede Wirabuana Putra, Wayan Maba, I Ketut Widnyana, and Anak Agung Ketut Sudiana

Table 2: EFAS (External Strategic Factor Analysis Summary) Matrix

\begin{tabular}{|c|c|c|c|c|}
\hline No. & External Strategy Factors & Weight & Ratting & Score \\
\hline$(1)$ & $(2)$ & $(3)$ & $(4)$ & $(5)$ \\
\hline & OPPORTUNITIES (+) & & & \\
\hline 1 & As a Spiritual Tourism Destination Based on Local Wisdom & 0.113 & 3,9 & 0.44 \\
\hline 2 & Tourism Area Development & 0.110 & 3.8 & 0.42 \\
\hline 3 & Economic Growth Increases & 0.108 & 3,7 & 0.40 \\
\hline 4 & Maintaining the Preservation of Cultural History Values & 0.112 & 3.8 & 0.43 \\
\hline 5 & Increased Village Community Welfare & 0.107 & 3,7 & 0.39 \\
\hline 6 & Opening Jobs & 0.110 & 3,7 & 0.41 \\
\hline & THREAT (-) & & & \\
\hline 1 & The purity and cleanliness of the area & 0.051 & 1.7 & 0.09 \\
\hline 2 & Order and Security & 0.054 & 1.9 & 0.10 \\
\hline 3 & Vehicle Volume & 0.045 & 1.5 & 0.07 \\
\hline 4 & Conflict Between Citizens & 0.049 & 1.7 & 0.08 \\
\hline 5 & Transfer of Land Functions & 0.048 & 1.6 & 0.08 \\
\hline 6 & Population density & 0.044 & 1.5 & 0.07 \\
\hline 7 & Total (O + T) & 0.049 & 1.7 & 0.08 \\
\hline & & 1.00 & & 3.05 \\
\hline
\end{tabular}

The results of the EFE (External Factors Evaluation) calculation for the development of the management of the sacred area of the Masceti temple are as a spiritual tourism destination based on local wisdom with a score of 0.44 , while the main threat is competition between residents with a score of 0.10 . Based on the analysis of the external environment above, the position of the external environment in the development of the management of the sacred area of the Masceti temple as a spiritual tourism destination based on local wisdom is in the "strong" category with a total score of 3,050. Thus, that the external position in developing the management of the sacred area of the Masceti temple as a spiritual tourism destination based on local wisdom is able to take advantage of the opportunity factor and be able to overcome the existing threat factors.

Table 3: Weighting and results of the SWOT questionnaire

\begin{tabular}{|c|c|c|}
\hline EFAS & S $=2.704$ & $\mathrm{~W}=0.468$ \\
\hline $\mathrm{O}=2.482$ & $\mathrm{SO}=5.186$ & $\mathrm{WO}=2,950$ \\
\hline $\mathrm{T}=0.565$ & $\mathrm{ST}=3.269$ & $\mathrm{WT}=1.033$ \\
\hline
\end{tabular}

Based on the weighting results (Table 3), a strategy is drawn up based on a combination of strategies that have the highest to the lowest values, such as the order of alternatives presented in the following strategies in Table 4:

Table 4: The sequence of alternative SWOT strategies

\begin{tabular}{|c|c|c|}
\hline No. & Stretegi & Weighted Value \\
\hline 1 & Weakness-Opportunity (WO) & 2,950 \\
\hline 2 & Strength - Opportunity (SO) & 5.186 \\
\hline 3 & Weakness-Threat (WT) & 1,033 \\
\hline 4 & Stength - Threat (ST) & 3.269 \\
\hline
\end{tabular}

Based on the various strategies in table 4, these strategies are broken down into various development programs that support each of these strategies, including:

1) SO (Strength-Opportunity) strategy, maintaining the environment of the sacred area of the Masceti temple, developing and arranging the sacred area of the Masceti temple as a tourist destination to support main tourism, namely spiritual tourism, Making tour packages with the nearest tourist area, maintaining local 
wisdom and culture and making rules / joint policies between official village managers and customary village managers regarding the management of the sacred area of the Masceti temple

2) ST (Strength-Threat) strategy, educates the public by providing counseling and training to the community regarding the management of the sacred area of the Masceti temple, strengthening institutions, and collaborating with related parties so that there is synergy for the continued development of the management of the sacred area of the Masceti temple

3) The WO (Weakness-Opportunity) strategy, optimizing the role of the Tourism Awareness group (POKDARWIS) in the management of the sacred area of the Masceti temple, structuring facilities and infrastructure, improving environmental cleanliness, establishing good partnerships, and creating an integration map that connects tourist destinations, and finalizing details structuring the sacred area of the Masceti temple to support the main tourism

4) The WT (Weakness-Threat) strategy, community development and empowerment, strengthening POKDARWIS, improving human resources through courses and skills training, collaborating with tourism education institutions, awareness and charm educators, creating a route map for the sacred area of the Masceti temple to see the potential owned, fostering and growing and developing local products.

\subsection{THE GENERAL STRATEGY (GRAND STRATEGY) FOR THE DEVELOPMENT OF THE MANAGEMENT OF THE PURA MASCETI SACRED AREA}

In accordance with the results of the analysis of internal and external environmental factors, the position of internal environmental factors in the development of the management of the Masceti temple sacred area is in the "strong" category with a score of 3.17, and the position of external environmental factors is also in the "strong" category with a score of 3.05. The total internal and external factor weight scores place in the development of the management of the sacred area of the Masceti temple in cell I in the IFE and EFE matrices, as presented in Table 5.

Table 5: Internal-External Matrix of the Pura Masceti Sacred Area

TOTAL VALUE OF IFE

\begin{tabular}{|c|c|c|c|c|}
\hline & 4.0 & $\begin{array}{l}\text { Strong } \\
3.173 .0\end{array}$ & $\begin{array}{c}\text { Moderate } \\
2.0\end{array}$ & $\begin{array}{c}\text { Weak } \\
1.0\end{array}$ \\
\hline $\begin{array}{l}\mathrm{T} \\
0 \\
\mathrm{~T}\end{array}$ & $\begin{array}{l}\text { Strong } \\
3,05 \\
3,0\end{array}$ & $\begin{array}{c}\text { I } \\
\text { Grow and build } \\
\text { (concentration via vertical } \\
\text { integration) }\end{array}$ & $\begin{array}{l}\text { II } \\
\text { Tumbuh dan bina } \\
\text { (kosentrasi melalui } \\
\text { horisontal) }\end{array}$ & $\begin{array}{l}\text { III } \\
\text { Perhatikan dan pelihara } \\
\text { (pertumbuhan berputar) }\end{array}$ \\
\hline $\begin{array}{l}\text { A } \\
\text { L }\end{array}$ & & $\begin{array}{l}\text { IV } \\
\text { Grow and build } \\
\text { (pause) }\end{array}$ & $\begin{array}{c}\mathrm{V} \\
\text { Maintain and maintain } \\
\text { (strategy doesn't } \\
\text { change) }\end{array}$ & $\begin{array}{c}\text { VI } \\
\text { Harvest and divestment (area runs out } \\
\text { or sells out vigilance) }\end{array}$ \\
\hline $\begin{array}{l}\text { V } \\
\text { A } \\
\text { L } \\
\text { U } \\
\text { E }\end{array}$ & $\begin{array}{l}\text { Moderator } \\
\quad 2,0\end{array}$ & $\begin{array}{l}\text { VII } \\
\text { Maintain and maintain } \\
\text { (diversification of } \\
\text { concentration) }\end{array}$ & $\begin{array}{c}\text { VIII } \\
\text { Harvest or divest } \\
\text { (verified konglemerat) }\end{array}$ & $\begin{array}{c}\text { IX } \\
\text { Harvested and verified (liquidation) }\end{array}$ \\
\hline $\begin{array}{l}\text { E } \\
F \\
E\end{array}$ & $\begin{array}{l}\text { Weak } \\
1.0\end{array}$ & & & \\
\hline
\end{tabular}

Source: Results of Internal and External Environmental Analysis Information:

IFE = Internal Factor Evaluation

$\mathrm{EFE}=$ External Factor Evaluation 
Maulana (2014) states that spiritual tourism has actually been practiced since time immemorial, people used to travel to visit places that were considered sacred and sacred, and consulted people who were considered holy according to community beliefs, the goal was to get answers. questions - questions that are sometimes difficult to answer. Questions related to the soul, spirituality or belief or religion motivate people to travel. Figure 1 depicts the development of the management of the sacred area of the Masceti temple, the internal conditions are strong and the external conditions faced are high, so the strategy that suits these cells is a growth strategy. For this type it is most appropriate to carry out an intensive strategy and integration. Three strategies are grouped into intensive strategies, namely market penetration, market development strategy and product development strategy. a) The market penetration strategy of marketing efforts is further enhanced to increase the market share of the sacred area of the Masceti temple, which can be pursued, among others, through the active role of tour guides in providing information that can satisfy visitors. The guide is expected to be able to provide information precisely, quickly, and to be able to sort out the information.

Selection of promotional media and effective promotion programs can increase the dissemination of information about the sacred area of the Masceti temple. tourism promotion can be done through cultural festivals, mass media and electronic media (social media). b) market development strategy is the introduction of existing products or services in a new area or consumer group. Market development strategies can be carried out by promoting such as continuous advertising on mass media, electronic media (social media), Medahan Village website, Gianyar Regency website, and other media. c) The product development strategy is an increase in sales by improving or modifying existing products or services in the sacred area of the Masceti temple in the form of activities that can support the development of the management of the sacred area of the Masceti temple, including the arrangement of a centralized souvenir shop, pesraman, meditation place, yoga places, holy bathing places, wifi center, information center, and arrangement of tourist destinations in the holy Masceti temple area. Local wisdom is a set of knowledge along with certain values and norms that come from the results of adaptation and the life experience of a community group in a certain location which then provides a form of certain patterns of thought and action as a way to live in harmony with the environment, with others, and with oneself (Djajadi, 2010) Local wisdom can be in the form of tangible (texture, architectural, traditional artwork) and intangible (value system, singing advice), and in terms of types of local wisdom consists of governance, value systems, procedures, and special provisions such as sensitive areas. and sacred areas / buildings (Darmawan, 2010 in Tamaratika and Rosyidie, 2017). The incorporation of local wisdom in tourism development can provide benefits in the economic, physical and socio-cultural fields of the local location (Tamaratika and Rosyidie, 2017). The development of tourism in a tourist destination will always be calculated with benefits and benefits for the community at large (Barreto and Giantari, 2015)

\section{CONCLUSIONS}

1) The potential for spiritual tourism that is owned in the sacred area of Masceti temple is yoga, meditation and holy bathing activities supported by the opportunity to enjoy the sunrise, views of a vast expanse of rice fields, enjoy typical seafood culinary delights, and supported by infrastructure such as easy access to locations, adequate telecommunication networks, electricity networks, street lighting and water installations.

2) Perceptions and attitudes of the people of Medahan Village towards the Development of the Management of the Sacred Area of Pura Masceti as a Spiritual Tourism Destination Based on Local Wisdom showed that $54.00 \%$ agreed that the area was developed into a spiritual tourism destination, arguing that it could increase the community's economic growth and encourage increased spiritual activity.

3) The right alternative strategy for developing the management of the sacred area of the Masceti temple as a spiritual tourism destination, namely a) finalizing the planning of the arrangement of the sacred area of the Masceti temple and implementing sustainable management, b) arranging the place for selling souvenirs, culinary delights and arranging the parking area, c) improving facilities supporting infrastructure such as toilets, garbage dumps, yoga places, meditation, holy baths and construction of Hindu dormitories. 
The Management Model of Masceti Pura Temple Area in Bali As A Spiritual Tourism Destination Based on Local Wisdom

\section{SOURCES OF FUNDING}

This research received no specific grant from any funding agency in the public, commercial, or not-for-profit sectors.

\section{CONFLICT OF INTEREST}

The author have declared that no competing interests exist.

\section{ACKNOWLEDGMENT}

Thanks are conveyed to the managers of the Postgraduate Program of Regional Development Planning and Environmental Management of Mahasaraswati Denpasar University, the thesis supervisors, and to reviewers who have provided the opportunity, time, and thoughts in completing the research and writing of this publication.

\section{REFERENCES}

[1] Barreto, M, \& Giantari, IGA. K, 2015. Strategy for the Development of Hot Water Tourism Objects in Marobo Village, Bobonaro Regency, Timor Leste, Udayana University E-Journal and Business 4.11: 773-796, ISSN: 2337-3067. (In Bahasa)

[2] Conrady R. \& Martin Buck. (2011. Trends and Issues in Global Tourism 2011, In Collaboration with Pia Viehl and Kartin Tittle. SpringerVerlag Berlin Heidelberg. Germany.

[3] Habibah, N., Yuliana, and Kasmita, 2016. Strategy for the Development of Infrastructure and Facilities for Lake Marambe Tourism Objects in Mandailing Natal Regency. E-journal Home Economic and Tourism, Vol 11, No.1. (In Bahasa)

[4] Irma, M., Yustri, H., Hakim, AL. 2015. Analysis of the Development of Pantai Indah Popoh Tourism as a Tourist Destination Region of Tulung Agung Regency. Journal of Business Administration S1 Universitas Brawijaya. (26) 2: 1-7. (In Bahasa)

[5] Djajadi, I. 2010. Scientific wisdom \& local wisdom: guidelines for the formulation of local wisdom in West Kalimantan. West Kalimantan Cultural Congress II. (In Bahasa)

[6] Kusuma, IGARD, \& Suryasih, IA. 2016. Spiritual Tourism Activities and Travel Motivation in Tanah Lot Tourism, Tabanan Regency. Journal of Tourism Destinations. (4) 2: 118-122 https://doi.org/10.24843/jdepar.2016.v04.i02.p21

[7] Kemenbudpar, 2009. Law of the Republic of Indonesia No. 10 of 2009. About Tourism. Indonesia. (In Bahasa)

[8] Ministry of Tourism, 2008, Regarding the 2018-2019 Strategic Plan. (In Bahasa)

[9] Kompas, 2014. Pursuing the target of 20 million foreign tourists, marine tourism becomes a mainstay. (In Bahasa) read: https://travel.kompas.com/read/2014/12/08/152600827/Kejar.Target.20.Juta.Wisman.Wisata.Bahari. So.Andalan? page = all . Downloaded December 15, 2020.

[10] Maulana, A. 2014. Spiritual Tourism Development Strategy in Badung Regency, Bali Province. Indonesian Tourism Journal. (9) 2: 125-133. (In Bahasa)

[11] Rangkuti, F. (2000). SWOT Analysis Techniques for Improving Business Cases. Jakarta: PT. Gramedia Pustaka Utama. 200 p. (In Bahasa)

[12] Smith, M., \& Kelly, C. (2006). Holistic tourism: Journeys of the self? Tourism Recreation Research, 31 (1), 15 24.

[13] Tamaratika, F., \& Rosyidie, A. 2017. Incorporation of Local Wisdom in the Development of Tourism Areas in the Coastal Environment. Journal of Sociotechnology. (16) 1: 125-133 https://doi.org/10.5 614 / sostek. itbj.2017.16.1.10. (In Bahasa)

[14] Yoeti, (1985). Introduction to Tourism Science. Bandung: PT. Space. Pg 181. (In Bahasa). 